\title{
KEBERADAAN GRAF DENGAN DIMENSI PARTISI BINTANG YANG DIBERIKAN
}

\author{
Violla Meylisa \\ Program Studi Matematika, \\ Fakultas Matematika dan Ilmu Pengetahuan Alam, Universitas Andalas, \\ Kampus UNAND Limau Manis Padang, Indonesia. \\ email : violla.meylisa@gmail.com
}

\begin{abstract}
Abstrak. Misalkan terdapat graf $G=(V, E)$. Untuk suatu titik $v \in V(G)$ dan suatu subhimpunan sebarang $S$ dari $V(G)$, jarak antara $v$ dan $S$ didefinisikan sebagai $d(v, S)=\min \{d(v, x) \mid x \in S\}$. Misalkan $\Pi=\left\{S_{1}, S_{2}, \cdots, S_{k}\right\}$ adalah partisi- $k$ dari $V(G)$. Representasi dari $v$ terhadap $\Pi$ adalah vektor- $k$ yang dilambangkan dengan $r(v \mid \Pi)=\left(d\left(v, S_{1}\right), d\left(v, S_{2}\right), \cdots, d\left(v, S_{k}\right)\right)$. Partisi $\Pi$ adalah partisi penyelesaian untuk $G$ jika untuk setiap $u, v$ di $V(G)$, berlaku $r(u \mid \Pi) \neq r(v \mid \Pi)$. Nilai minimum $k$ yang ada untuk partisi- $k$ penyelesaian dari $V(G)$ dinamakan dimensi partisi dari $G$, yang dilambangkan dengan $p d(G)$. Partisi $\Pi=\left\{S_{1}, S_{2}, \cdots, S_{k}\right\}$ adalah partisi- $k$ penyelesaian bintang untuk $G$ jika partisi dari $V(G)$ dan masing-masing subgraf dari $G$ yang mengandung $S_{i}$, untuk $1 \leq i \leq k$ adalah bintang. Minimum $k$ yang mengandung partisi- $k$ penyelesaian bintang dari $V(G)$ dinamakan dimensi partisi bintang dari $G$ yang dilambangkan $\operatorname{spd}(G)$. Pada makalah ini akan dikaji kembali makalah [3] yang membahas tentang keberadaan graf dengan dimensi partisi bintang yang diberikan.

Kata Kunci: Partisi Penyelesaian, Dimensi Partisi, Dimensi Partisi Bintang, Graf Bintang
\end{abstract}

\section{Pendahuluan}

Misalkan terdapat graf terhubung $G=(V, E)$. Misalkan terdapat dua titik $u$ dan $v$ di $G$. Jarak dari $u$ ke $v$ adalah panjang lintasan terpendek antara $u$ dan $v$ pada $G$ yang dinotasikan dengan $d(u, v)$. Misalkan $\Pi=\left\{S_{1}, S_{2}, \cdots, S_{k}\right\}$ adalah partisi- $k$ dari $V(G)$. Maka representasi dari $v$ terhadap $\Pi$ adalah vektor- $k$ yang dilambangkan dengan

$$
r(v \mid \Pi)=\left(d\left(v, S_{1}\right), d\left(v, S_{2}\right), \cdots, d\left(v, S_{k}\right)\right)
$$

Partisi $\Pi$ adalah suatu partisi penyelesaian (resolving partition) untuk $G$ apabila $k$-vektor $r(v \mid \Pi)$ berbeda untuk setiap $v \in V(G)$. Nilai minimum $k$ sedemikian sehingga terdapat partisi $k$ penyelesaian dari $V(G)$ dinamakan dimensi partisi dari $G$, dilambangkan dengan $p d(G)$. Partisi $\Pi=\left\{S_{1}, S_{2}, \cdots, S_{k}\right\}$ dikatakan suatu partisi- $k$ penyelesaian bintang untuk $G$ jika partisi penyelesaian dari $V(G)$ dan setiap subgraf yang diinduksi oleh $S_{i}, 1 \leq i \leq k$ adalah graf bintang. Graf bintang $K_{1, n}$ didefinisikan sebagai graf dengan satu titik berderajat $n$ dan $n$ buah titik berderajat 1 . 


\section{Keberadaan Graf dengan Dimensi Partisi Bintang yang Diberikan}

Notasi $\sigma(G)$ menyatakan jumlah dari derajat ujung dari titik-titik utama graf $G$, $\sigma_{b}(G)$ merupakan jumlah derajat ujung dari cabang titik-titik utama $G$, ex $(G)$ adalah banyak titik-titik mayor eksterior dari $G$ dan $e x_{b}(G)$ adalah banyak cabang titik-titik mayor eksterior dari graf $G$.

Minimum kardinalitas dari partisi bintang induksi dari graf $G$ disebut banyaknya bintang terinduksi dari $G$ dan dilambangkan $s p(G)$. Graf $P_{n}$ adalah graf lintasan dengan panjang $n$, yang berawal dari titik $v_{1}$ dan berakhir di titik $v_{n}$. Derajat ujung dari titik mayor $v$ dilambangkan $\operatorname{ter}_{T}(v)$, dan $\operatorname{ter}(v)$ adalah banyaknya titiktitik ujung dari $v$. $Q_{i j}$ adalah sub lintasan dari $P_{n}$. Selanjutnya, $s p(\underbrace{T_{1 \cdots 1}})$ adalah banyaknya bintang terinduksi dari $T$, dimana $1 \cdots 1$ sebanyak $p$ buah.

Teorema 2.1. [3] Untuk $n \geq 1$, diperoleh

$$
\operatorname{sp}\left(P_{n}\right)=\operatorname{spd}\left(P_{n}\right)=\left\lceil\frac{n}{3}\right\rceil .
$$

Bukti. Karena bintang-terinduksi dari lintasan bisa mempunyai paling banyak tiga titik, maka teorema tersebut berlaku.

Teorema 2.2. [3] Untuk suatu graf pohon T yang tidak isomorfik dengan lintasan maka

$$
\operatorname{spd}(T)=\sigma_{b}(T)-e x_{b}+\operatorname{sp}(\underbrace{T_{1 \ldots 1}}) .
$$

Pada Teorema 2.3 berikut akan ditunjukkan bahwa selalu terdapat suatu graf terhubung dengan dimensi partisi bintang yang diberikan.

Teorema 2.3. [3] Untuk sebarang dua bilangan bulat a dan b sedemikian sehingga $3 \leq a \leq b$ terdapat sebuah graf terhubung $G$ sedemikian sehingga $p d(G)=a$ dan $\operatorname{spd}(G)=b$.

Bukti. Kasus 1. $a<b$.

Misalkan $n=3(b-a)+2$ dan $G$ adalah graf yang diperoleh dari lintasan $P_{n}$ dengan menambahkan sebanyak $a$ titik ujung $x_{1}, \cdots, x_{a}$ ke salah satu dari dua titik ujung dari lintasan tersebut, yang dilambangkan dengan $y$. Misalkan $z$ adalah titik dari lintasan awal $P_{n}$ yang bertetangga dengan $y$.

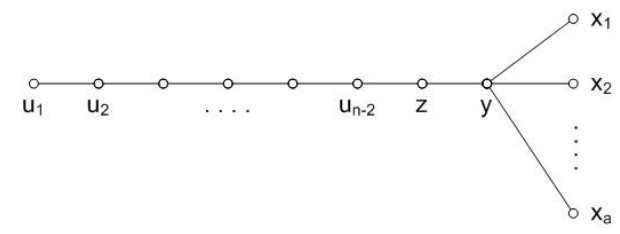

Gambar 1. Graf $G$, titik $z$ bertetangga dengan titik $y$ 
Titik-titik $x_{1}, \cdots, x_{a}$ mempunyai jarak yang sama ke sebarang titik lain dari graf $G$, oleh karena itu titik-titik $x_{1}, \cdots, x_{a}$ mempunyai kelas yang berbeda pada partisi penyelesaian dari graf $G$. Diperoleh bahwa $p d(G) \geq a$.

Selanjutnya, diperoleh bahwa partisi dengan kelas

$$
\left\{x_{1}, y, z\right\},\left\{x_{2}\right\} \cup V\left(P_{n} \backslash\{y, z\}\right),\left\{x_{i}\right\}, 3 \leq i \leq a
$$

adalah partisi penyelesaian, oleh karena itu $\operatorname{pd}(G)=a$.

Misalkan partisi $\Pi$ adalah himpunan kelas $S_{i}$, untuk $1 \leq i \leq a$, yaitu $\Pi=$ $\left\{S_{1}, S_{2}, \cdots, S_{a}\right\}$, dengan

$$
\begin{aligned}
S_{1} & =\left\{x_{1}, y, z\right\}, \\
S_{2} & =\left\{x_{2}\right\} \cup V\left(P_{n}-\{y, z\}\right)=\left\{x_{2}, u_{1}, u_{2}, \cdots, u_{n-2}\right\}, \\
S_{3} & =\left\{x_{3}\right\} \\
\vdots & \\
S_{a} & =\left\{x_{a}\right\} .
\end{aligned}
$$

Representasi semua titik di graf $G$ terhadap $\Pi$ adalah

$$
\begin{aligned}
r\left(u_{1} \mid \Pi\right) & =(n-2,1, \cdots, n), \\
r\left(u_{2} \mid \Pi\right) & =(n-3,0, \cdots, n-1), \\
\vdots & \\
r(z \mid \Pi) & =(0,2, \cdots, 2) \\
r(y \mid \Pi) & =(1,1, \cdots, 1) .
\end{aligned}
$$

Dapat dilihat bahwa representasi setiap titik di graf $G$ berbeda satu sama lain.

Dari Teorema 2.1 dan Teorema 2.2 diperoleh bahwa $y$ adalah satu-satunya titik mayor eksterior di graf $G$ dan $\operatorname{ter}(y)=a+1$, diperoleh

$$
\begin{aligned}
\operatorname{spd}(G) & =\sigma_{b}(T)-e x_{b}+\operatorname{sp}(\underbrace{T_{1 \ldots 1}}) \\
& =a+1-1+s p\left(P_{n-3} \cup y x_{1}\right), \\
& =a+s p\left(P_{3(b-a)}\right) \\
& =a+b-a=b .
\end{aligned}
$$

Kasus 2. $a=b$.

Misalkan graf $G$ adalah bintang $S_{a}$.

Titik-titik $x_{1}, \cdots, x_{a}$ mempunyai jarak yang sama ke sebarang titik lain dari graf $G$ yaitu titik $y$, oleh karena itu titik-titik $x_{1}, \cdots, x_{a}$ berada di kelas yang berbeda. Misalkan $\Pi$ adalah himpunan kelas $\left\{S_{1}, S_{2}, \cdots, S_{a}\right\}$, dengan

$$
\begin{gathered}
S_{1}=\left\{x_{1}, y\right\}, \\
S_{2}=\left\{x_{2}\right\}, \\
\vdots \\
S_{a}=\left\{x_{a}\right\} .
\end{gathered}
$$

Akan ditunjukkan bahwa representasi setiap titik berbeda. 


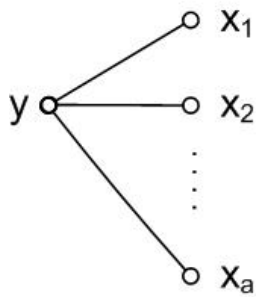

Gambar 2. Graf $G$

Representasi semua titik terhadap $\Pi$ adalah

$$
\begin{aligned}
r\left(x_{1} \mid \Pi\right) & =(0,2, \cdots, 2), \\
r\left(x_{2} \mid \Pi\right) & =(2,0, \cdots, 2), \\
\vdots & \\
r\left(x_{a} \mid \Pi\right) & =(2,2, \cdots, 0) .
\end{aligned}
$$

Dapat dilihat bahwa representasi setiap titik berbeda, sehingga $\Pi$ merupakan himpunan penyelesaian, dan $p d(G)=a$.

Dari Teorema 2.1 dan Teorema 2.2. $\sigma_{b}(G)$ merupakan banyaknya sisi yang bersisian dengan titik $y$ dan $e x_{b}(G)$ adalah banyaknya sisi yang bersesuaian dengan $y$ setelah menghapus semua titik $x_{2}, \cdots, x_{a}$. Diperoleh

$$
\operatorname{spd}(G)=\sigma_{b}(T)-e x_{b}+\operatorname{sp}(\underbrace{T_{1 \cdots 1}})=a-1+\operatorname{sp}\left(y x_{1}\right)=a-1+1=a .
$$

Sehingga diperoleh,

$$
\operatorname{pd}(G)=\operatorname{spd}(G)=a
$$

\section{Kesimpulan}

Misal diberikan bilangan bulat positif $a$ dan $b$ sedemikian sehingga $3 \leq a \leq b$. Dalam makalah ini telah dikaji kembali bahwa terdapat graf terhubung $G$ dengan $p d(G)=a$ dan $\operatorname{spd}(G)=b$, untuk $a<b \operatorname{dan} p d(G)=\operatorname{spd}(G)=a$, untuk $a=b$, seperti yang telah dipaparkan dalam [3].

\section{Ucapan Terima kasih}

Penulis mengucapkan terima kasih kepada Ibu Dr. Lyra Yulianti, Ibu Dr. Yanita, Bapak Dr. Admi Nazra, Bapak Bukti Ginting M.Si dan Bapak Drs. Syafruddin, M.Si yang telah memberikan masukan dan saran dalam penyempurnaan penulisan artikel ini.

\section{Daftar Pustaka}

[1] Chartrand, E. Salehi, P. Zhang, 2000, The Partition Dimension of A Graph, Aequationes Math. 59 : $45-54$ 
Keberadaan Graf dengan Dimensi Partisi Bintang Tertentu 79

[2] Harary, F., 1969, Graph Theory. Addison-Wesley Publishing Company, Inc.

[3] Marinescu-Ghemeci, 2012, On Star Partition Dimension of Trees, Math. Reports $14(64): 161-173$

[4] Munir, R., 2005, Matematika Diskrit, Informatika 